URL: http://dergipark.ulakbim.gov.tr/ijhbs/index

Volume: 1, Issue: 3, Year: 2015

http://dx.doi.org/10.19148/ijhbs.34349

\title{
How Affective Keeping Mainstreamed Referred Student' Study Records With Individualized Memory Stick (Flash Memory) On Their Motivation
}

\author{
Hakan Uşaklı \\ Sinop University, Turkey \\ husakli@yahoo.com
}

\begin{abstract}
Problem Statement: This manuscript is about effectiveness of using flash memory that is individualized memory stick for referred as mainstreamed students' motivation. It is apparently known that there are referred as mainstreamed children who need individualized education program (IEP) one to ten ratio. This is really troublesome not only for teacher but also school counselor. Professionals think that two referred as mainstreamed students are normal number for any class contain twenty four students. But there are some cases when the referred as mainstreamed students increased five this is really unwanted sudation for all school bodies. Teachers really facing trouble when they have to devote their time to those two different groups. When the teacher answer the question of normal student the mainstreamed one losing his or her attention and start to broke up class climate. This situation is valid for counterpart. Lots of homework in other words many of collected papers that require teacher and counselor check can have problems. It is pity that this situation is both time consuming and waste of material that's why no one have enough time to look close to them. The lost, forgotten or unfinished materials (especially homeworks) starts home wars between parents and students. Individualized memory stick (I Stick) or Bireysel Bellek [(in Turkish)(B Bellek)] is a kind of record program that contains student personal appraisal is a rescue for families, classroom teachers, counselors, friends and students for enhancing motivation.

Purpose of Study: The purpose of the study is to investigate effectiveness of I Stick for mainstreamed-referred fourth grades students on motivation.

Methods: This study is conducted as experimental study. Quantitative data gathering research methods used in the study. Motivation in education scale in education applied to 668 fourth grade students. Experimental, control and placebo of three groups are constituted.

Findings and Results: In the pre-test the average of motivation levels of experiment, control, and placebo groups are close to each other, respectively: $37.16,37.31$, and 37.27 . The post-test shows that the average of motivation level experimental group increased, and control and placebo group did not changed. In the follow-up test in three weeks the results shows that the groups' motivation levels found to be similar to post-test results. Results show that there was significant difference between experiment, placebo and control groups. Using I Stick has positive effect on student motivation and this positive affect prolong three weeks interval.

Conclusions and Recommendations: Using I Stick is highly influential on student motivation. All mainstreamed referred students are positively affected I Stick. I Stick is useful for collect, follow up, interpret and draw conclusion records about IEP students on their motivation. Students who have high motivation is also well come for the people around the IEP student. Future studies should conduct among different age, sex and domains such as anxiety, social emotional learning.
\end{abstract}

Keywords: Mainstreamed Students, Individualized Memory Stick, Motivation

\section{Introduction}

Semi-annual counselors meeting's main issue was "Who will be responsible for keeping records of individualized education programs' (IEP) students?" (Sinop RAM, 2012). 50\% of the counselors $(n=25)$ complained about their work, overloaded responsibilities such as orientation 
programs, individual counseling and family meetings. Not only giving courses but also keeping records of whatever they do also create problems for elementary teachers. Several students (one or two) seem to be acceptable (Klingner, et al., 1998) in a class consisting of twenty four students (Hocutt, 1996). Exact number is 1 mainstreamed student in 35 normal students 2 mainstreamed students in 25 normal students are acceptable (ORGM, 2015). However, when there are four to six mainstreamed students in a class of fifty or more students in total, there occur many problems concerning the other students' attention, classroom management and the teacher's workload.

USB (universal serial bus, a high-speed bus commonly used for connecting peripheral devices to computers.) flash drive is a portable solid state storage device nicknamed "pen drive" or keychain drive" that plugs directly into a computer's USB port (Parsons \& Oja, 2014: 769). Solide state storage (sometimes called flash memory) is a technology that stores data in erasable, rewritable circuitry, rather than on spinning disks or streaming tape, it is widely used in portable consumer device, such as digital cameras, portable media players, iPods, and cell phones. It is also used as an alternative for hard disk storage in some laptop computers. Some solid storage is removable and provides fairly fast access to data. It is an ideal solution for storing data on mobile devices and transporting data from one device to another (Parsons \& Oja, 2014).

In I Stick there are four pages written in Excel program. These pages are easy to understand and use. I Stick was developed with an inspiration of digital portfolio. In 2006-07, JES (Youth Competence Center) created an innovative digital portfolio called C-stick with the help of European funding. The objective was to develop a competence framework and tools for self, peer and expert key competency assessment (Froy \& Payne, 2011).

An important criterion for this framework was the accessibility for a low-skilled target group, so very straightforward vocabulary was used and an attractive and easy- reference interface and simple navigation structure was designed. A second criterion was that it should be usable in different settings (leisure time activities, training, job counseling), regardless of professions or sectors. Because of this, the C-stick has been actively used by the local Competency Centers. The $\mathrm{C}$-stick is a central database (on a USB flash drive) where young people can gather and store all kinds of relevant information; it provides them with a framework for personal development plans and it contains a tool to create adjusted CVs. The portfolio on the USB flash drive is also connected to a server in order to keep a backup of the data, as well as being linked to an administrative system through which the tutors can send files and competence assessments to their pupils (p.31).

The portfolio was created on a USB flash drive which is a very well-known and attractive tool to young people. It has several other advantages: firstly it can be permanently updated. Secondly it's also a concrete and tangible tool as young people can carry it with them at any moment, unlike an e-portfolio on a website. However, the C-Stick portfolio on the USB flash drive is also connected via the internet to a server, in order to keep a backup of the data. It's also linked to an administrative system by which tutors can send files and competence assessments to their pupils (JES, 2013).

Youngsters in large cities who often did not finish their school and hang around in the streets because they are unemployed are guided by an organization who makes them aware of the importance of generic skills, helps them in the development and also registers their achievements in a digital portfolio called C-Stick (memory stick about competencies). In this project, the youngsters learn to improve their key skills and they get an accreditation on their digital portfolio (Trock, 2009; Van de Maele, 2009). 
JES in Antwerp project is widely related to competence which is combination of ability, view point, family structure, friendship formation, ethnic identity, belief in short socio-economic status (SES) of youth. In this point of view Smid (2011) drew a frame about the C stick.

The youth workers form JES Antwerp had developed a specific method in order to acknowledge the strengths of adolescents and to build further on that. This method was called the C-Stick, which was a digital portfolio with a personal development plan. The C-Stick included a set of techniques for recognizing skills and developing competences. The key elements were: observation skills, feedback, group dynamics, peer learning and experiential learning. In practice, not every youth worker used this method in their work. One of the Flemish youth workers explained that the use of the C-Stick was particularly useful in building someone's resume. But in her own work she preferred to observe the adolescents and work from there. One of the Flemish youth workers saw motivation as the most important task in his work. He called himself a "motivator" (motivator). According to him, motivating adolescents is essential given their lack of trust in the government. As a youth worker he must use a different approach to reach the adolescents than the government does, so they would not see him as part of the government (p.17$18)$.

I stick is stands for impersonal memory stick. Impersonal means the memory stick is using for only one mainstreamed children. Memory stick is widely known as flash memory (Froy \& Payne, 2011). Flash memory is a type of nonvolatile memory that erases data in units called blocks. A block stored on a flash memory chip must be erased before data can be written, or programmed, to the microchip. Flash memory retains data for an extended period of time whether a flashequipped device is powered on or off (Christensson, 2006).

\subsection{Similarities and Differences between C Stick and I Stick}

Both C Stick and I Stick are flash memories based on educational technology and they are used for the benefit of the teenager. Overall C Stick was developed for youth aged 13-18 years old whereas I Stick was developed for the children aged 7-10 years old. C Stick is a digital portfolio which contains the youth's competence. I stick is a USB flash based on collection of individualized education program's activities. I Stick also contain appraisals of student. The curricula difference between C Stick and I Stick is that: the C Stick is connected with internet but I Stick never connects with computer that has internet connection. For this reason, in I stick there is no system administration.

\subsection{Philosophy of I Stick}

I Stick is mainly about "Individualized Education Program Strictly Click Keeping". This apparatus is technologized (technology-based) for record keeping of student appraisals. The philosophy of I Stick combines two basic student appraisals. One is classic or orthodox method of student appraisals. According to the classic view, there are two classifications: test techniques and non-test techniques (Ozguven, 1997; Kuzgun, 1997; Yesilyaprak, 2002; Kutlu \& Kaya, 2005). Another one is the modern approach which only uses the appraisal of students' place in comprehensive developmental guidance and counseling school based programs (Nazli, 2011; Korkut, 2007). The role of I Stick is join this two views. The school counselor has collect information about the student. The class teacher own ideas on the students. The family of the student is responsible for student' doing her or his homework. All this three deferent data can be kept in I Stick.

\subsection{Physical Features of I Stick}

I Stick is a flash memory (data carrying device) which connects with USB hubs of computers. It can be either $2 \mathrm{~GB}$ or more $32 \mathrm{~GB}$ circuits. When the device is connected to the computer, it starts working and tiny lights flash on it. In this study, different brands and varying capacities of I stick were used. 


\subsection{Content Features of I Stick}

Each I Stick covers personal information of individual user (IEP). There is a program written in Excel present in the I Stick. The Excel pages contain newly shot photos of the student representing the interaction of the pupil with his/her family, friends, teachers and counselors. Four different pages are colored in four different colors. White pages can be seen by "everybody" yellow by "only his/her family", green by "the teacher", red by the "counselor". Each page in the I Stick contains information about the students' home, environment, and school and class settings. Moreover, there is a page which is confidential so it keeps the student's privacy including his/her ideas, hunches, deep interpretations, dreams, and even hopes about the future. These mainly personal records are gathered from appraisals of students. Only the red page is coded and only the students know the red page's code. The white page is the first and the front page and is seen when the program is started.

\subsection{Hidden Codes in I Stick}

Due to the I Stick developed for IEP children, codes or passwords were developed under the ethical principles of keeping special information about IEP children (PDR-DER, 2007). The studies of code development have been continuing. The basic philosophy of codes in I Stick depends on interaction model of counting friendship skills (Usakli, 2006).

\subsection{Technology in IEP}

From early computers to today's high tech mobile phones, people have been using many software programs in their education life. E-mails, social sharing pages (blogs, twitters, Facebook etc.) are developments of 21 st age utilities. This rapid development also helps providers for IEP students. Researchers have been pointing out new ways of how families, schools' personnel and other specialists can make use of this life easing facilities (Campbell \& Mechling, 2009; Kelley, Barholomew \& Test, 2011).

If we consider that the technology enhances student motivation from the perspective of selfdetermination, there must be more in depth theoretical studies. Field, Sarver and Shaw (2003) used assisted technology in their study to enlarge intrinsic motivation.

\subsection{Motivation and IEP Student}

Motivation is indicated by the intensity (or energy), direction, and persistence of a goal-directed behavior or action (Dai \& Sternberg, 2008: 11). Motivation is a quantity that people have in varying degrees and, if they have enough of it, their intellectual performance will fully reflect their cognitive abilities (Dweck, Mangels \& Good, 2008: 41).

Motivation attempts to explain the "what," "why," and "where" of a person's more or less conscious praxis and practice. By praxis we mean cognitive or motor goal-directed actions addressed to the environment, to satisfy central and intrinsic personal needs (i.e., affective goals). Practice is similar to a conscious or unconscious praxis that often uses automatized operations, and is enacted to satisfy marginal and predominantly extrinsic needs or affective goals. Motivation interfaces or intertwines the organism's affects-emotions and knowing functions with the nature (constraints or resistances) of external-internal reality and the person's activities in this environment (Pascual-Leone \& Johnson, 2008: 198-199).

There are studies expressing how effective of technology on students' motivation (Heafner, 2004; Star et al., 2014; Cramer \& Smith, 2002).

Last ten years' studies on motivation have been focusing on Deci and Riyan (2000), Riyann and Deci (2000) studies. This new perspective known as self-determination theory is conducted by scientific approaches (Deci \& Riyan, 2000). In this perception, motivation is people's initiative and continuity on behaviors to the extent that they believe the behaviors will lead to the desired outcomes or goals. 
Besides, overall IEP is a process which intends to facilitate more motivation and greater ability to achievement (Barnard-Brak \& Lechtenberger, 2010). This notion is valid for elementary level courses such as mathematics (Avant \& Heller, 2011) and physical education (Downing \& Rebollo, 1999). Using technology in IEP is also affective to enhance motivation (Campbell and Mechling, 2008). Handley (2010) point out that the increase learning motivation and skills through computer technology for students with behavioral and/or learning difficulties. Using technology making homework effective not only for normal students but also mainstreamed referred students (Carr, 2013). The aim of this study is to find out the effectiveness of I Stick on IEP students' motivation. In this reason the study conducted as experimental research design.

\section{Method}

\subsection{Research model}

Experimental research design was appropriate for the study so it was used in this study so there are three groups in this study: experimental, control and placebo groups. Experimental designs (also called intervention studies or group comparison studies) are procedures in quantitative research in which the investigator determines whether an activity or materials make a difference in results for participants. You assess this impact by giving one group one set of activities (called an intervention) and withholding the set from another group (Creswell, 2012: 21). The basic intent of an experimental design is to test the impact of a treatment (or an intervention) on an outcome, controlling for all other factors that might influence that outcome (Creswell, 2009: 148-149). Placebo group was delivered a memory stick but it didn't involve the Excel program. Control group was not delivered a memory stick.

Three groups (experimental, control, placebo) were each tested at three times (pretest, posttest, follow-up test). Table 1 contains an outline of the design and number of students in each group at each testing time. The short-term effectiveness of the I stick in comparison to the control and placebo groups was assessed in the first part of the study (weeks 1-5). The longer-term effectiveness of the i stick was assessed by comparing the scores of students in the experimental, control and placebo groups at follow-up to their own pretest scores and to the follow-up scores of students in the no-treatment groups.

Table 1: Design of the Study

\begin{tabular}{llll}
\hline Week & Experimental & Placebo & Control \\
\hline 1 & Pretest $(\mathrm{n}=32)$ & Pretest $(\mathrm{n}=32)$ & Pretest $(\mathrm{n}=32)$ \\
$2-6$ & Using I stick & Memory stick not contain personal info & No contact \\
7 & Posttest $(=32)$ & Posttest $(=32)$ & Posttest $(=32)$ \\
10 & Follow-up test $(\mathrm{n}=32)$ & Follow-up test $(\mathrm{n}=32)$ & Follow-up test $(\mathrm{n}=32)$ \\
\hline
\end{tabular}

The experimental and placebo groups delivered memory sticks. Experimental group' memory sticks called as I stick that's why this memory sticks contain excel program to keep students data about personal information, homework and teachers perceptions. This treatment occurred two hours in a weak in four weeks. Placebo group' flash memories do not contain excel program. These flash memories only contained flash games. Students who are in placebo group allowed to play flash games during two sessions.

\subsection{Participants}

Here is demographic characters of participants in the study. 668 fourth grade students (365 male 303 female) participated in this study. This sample is selected from primary schools in Sinop, the northernmost part of Turkey. Sinop is a peninsula situated on Black Sea shore. Written permission is received from school principals and families. 93 IEP students participated in the motivation scale and they were chosen by referring to the guidance research center's criteria to detect students 
with low IQ also have low motivation scores. Motivation in education scale in education applied to 668 fourth grade students. 96 students who were labeled as mainstreamed and also lower motivation scores selected. From those 96 students randomly assigned three groups. Mean of student' age is 9 years 4 mounts.

\subsection{Instruments}

In this study Motivation in Education Scale (Kara, 2008) was used. The scale was adapted by Kara (2008) from original form of French known as "Echelle de Motivation en Education" developed by Vallerand et al. (1992). 12 items the scale' Cronbach Alpha reliability coefficient was calculated for all scale and for each factor to determine the internal consistency of scale, then the correlation coefficient between the test - retest too, were sufficient. According to analysis, this scale is valid and reliable in determining the elementary students' motivation to education. Four different factors Cronbach Alpha reliability coefficients are identified external motivation $(\alpha=.79)$, amotivation $(\alpha=.78)$, inner reflected external motivation $(\alpha=.80)$, internal motivation $(\alpha=.78)$

\section{Findings}

In this study the effectiveness of using I stick that is impersonal or individualized flash memory on mainstreamed referred children' motivation has examined. The equal three groups not only in number but also in motivation level after four weeks intervention and after three weeks followup compared in terms of students' motivation level. Here is four table illustrating three groups and three measures statistical points.

Table 2: Descriptive Statistics

\begin{tabular}{lccccccccc}
\hline Group & \multicolumn{3}{c}{ Pretest } & \multicolumn{3}{c}{ Posttest } & \multicolumn{3}{c}{ Follow-up test } \\
\cline { 2 - 9 } & $\mathrm{N}$ & $\bar{X}$ & $\mathrm{~S}$ & $\mathrm{~N}$ & $\bar{X}$ & $\mathrm{~S}$ & $\mathrm{~N}$ & $\bar{X}$ & $\mathrm{~S}$ \\
\hline Experiment & 32 & 37.16 & 2.61 & 32 & 43.88 & 1.94 & 32 & 44.53 & 2.00 \\
Control & 32 & 37.31 & 2.08 & 32 & 37.03 & 1.71 & 32 & 37.16 & 1.64 \\
Placebo & 32 & 37.27 & 2.25 & 32 & 36.66 & 1.77 & 32 & 37.44 & 2.29 \\
\hline
\end{tabular}

Table 2 illustrates descriptive statistics of three groups that are experimental, control and placebo in three different measurements as flows pretest, posttest and follow-up tests. As seen from table mean points are close each other in pretest of three different groups contained 32 students each. To know whether or not there are equality between each group before treatment test of homogeneity of variances and one way anova tests calculated.

Table 3: Test of Homogeneity of Variances

\begin{tabular}{lcccc}
\hline & Levene Statistic & df1 & df2 & Sig. \\
\hline pretest & .544 & 2 & 93 & .582 \\
posttest & .500 & 2 & 93 & .608 \\
follow up test & .647 & 2 & 93 & .526 \\
\hline
\end{tabular}


Table 4: ANOVA

\begin{tabular}{rccccc}
\hline & $\begin{array}{c}\text { Sum of } \\
\text { Squares }\end{array}$ & df & $\begin{array}{c}\text { Mean } \\
\text { Square }\end{array}$ & F & Sig. \\
\hline Pretest Between Groups &, 646 & 2 &, 323 & & \\
Within Groups & 504,312 & 93 & 5,423 &, 060 &, 942 \\
Total & 504,958 & 95 & & & \\
\hline Posttest Between Groups & 916,271 & 2 & 458,135 & & \multirow{2}{*}{000} \\
Within Groups & 305,688 & 93 & 3,287 & 139,380 & \\
Total & 1221,958 & 95 & & & \\
Follow-up test Between & 1117,771 & 2 & 558,885 & & \\
Groups & 372,062 & 93 & 4,001 & 139,698 & \\
Within Groups & 1489,833 & 95 & & & \\
Total & & & & & \\
\hline
\end{tabular}

Table 3 and 4 illustrates there is no significant difference between groups in pretest.

Table 5: ANOVA Results of Repeated Measures

\begin{tabular}{lcccccc}
\hline $\begin{array}{l}\text { Source of } \\
\text { Variance }\end{array}$ & $\begin{array}{c}\text { Sum } \\
\text { Square }\end{array}$ & df & $\begin{array}{c}\text { Mean } \\
\text { Square }\end{array}$ & F & p & $\begin{array}{c}\text { Significant } \\
\text { Difference }\end{array}$ \\
\hline Between Subjects & 2176.000 & 95 & 22.905 & & & \\
Measure(Pretest- & 353.250 & 2 & 176.625 & 32.245 & .000 & $\begin{array}{c}\text { Posttest- } \\
\text { Posttest-follow up }\end{array}$ \\
$\begin{array}{l}\text { Pest) } \\
\text { Error }\end{array}$ & & & & & $\begin{array}{c}\text { Pretest, Follow } \\
\text { up-test, Pretest }\end{array}$ \\
Total & 1040.750 & 190 & 5.478 & & & \\
\hline
\end{tabular}

In Table 5 there is pretest, posttest and follow-up test there is significant difference between groups $[\mathrm{F}(2-190)=32.245, \mathrm{p}<.01]$.

Posttest experimental group' motivation mean point $(\bar{X}=43.88)$ and follow-up experimental group' motivation mean point ( $\bar{X}=44.53$ ) are higher than pretest experimental group' motivation mean point ( $\bar{X}=37.16$ ). In addition for this there is no significant difference between posttest and follow-up test of experimental group' motivation mean points. This findings validate that using impersonal stick enhance mainstreamed students motivation. This high motivation expulsing three weeks after intervention.

\section{Discussion and Conclusion}

Enhancing mainstreamed student motivation is one of widely study subject for researchers (Levy \& Campbell, 2008; Smith, Sinclair \& Chapman, 2002). Using technology to empower mainstreamed student' motivation is an another issue for scholars (Campbell and Mechling, 2008; Handley, 2010). Impersonal stick is ordinary flash memory contains excel program which has open opportunity keeping student' records. I stick firstly used as competence stick (C Stick) by SALTO as European Union educational project in Belgium since 2006 Froy and Payne, 2011). This study is parallel with Van de Maele (2009) description of C stick that is as fallows enhance social orientation, create a link between different settings such as leisure time activities, training and create an integrated learning experience. Using I stick is effective motivator for mainstreamed student as seen in this study finding like indicated in Smid (2011) literature review study.

Motivation is crucial for student life. Motivation effects on cognitive strategies, academic performance, attention and cognitive processing and vulnerability to stereotype threat. I stick not only useful for students but also it utilizes adults such as teachers and parents who want to organize their works about students. Student can fallow her or his development via I stick. Parents 
also release how their students improve in school life. Teachers can compare their students with the help of I stick.

In future researcher who wants to use technology to maximize child or youth motivation can use flash memories that have operational programs for keeping records of students. This study conducted with exceptional population we need normal population with different age groups.

\section{References}

Avant, M.J.T. \& Heller, K.W. (2011). Examining the Effectiveness of TouchMath With Students With Physical Disabilities. Remedial and Special Education ( 32) 309-321.

Barnard-Brak, L. \& Lechtenberger, D.A. (2010). Student IEP Participation and Academic Achievement Across Time. Remedial and Special Education, (31), 343-349.

Bitter, G. G. \& Legacy, J. M. (2008). Using Technology in the classroom $\left(7^{\text {th }} \mathrm{ed}\right)$. Boston: Pearson Publishers.

Carr, N. S. (2013). Increasing the Effectiveness of Homework for All Learners in the Inclusive Classroom. School Community Journal, 23, (1). 169-182.

Campbell, M.L. \& Mechling L.C. (2009). Small Group Computer-Assisted Instruction With SMART Board Technology: An Investigation of Observational and Incidental Learning of Nontarget Information. Remedial and Special Education, (30) 47-57.

Christensson, P. (2006). Flash Memory Definition. Retrieved 2015, Nov 22, from http://techterms.com

Creswell, J. W. (2012). Educational research: Planning, conducting, and evaluating quantitative and qualitative research ( $4^{\text {th }}$ ed.). Boston, MA: Pearson.

Creswell, J. W. (2009). Research design: Qualitative, quantitative, and mixed methods approaches ( $3^{\text {rd }}$ ed.). California: Sage.

Cramer, S. \& Smith, A. (2002). Technology's impact on student writing at the middle school level. Journal of Instructional Psychology, 29(1). 3-14.

Dai, D. Y. \& Sternberg, R. J. (2008). Beyond Cognitivism: Toward an Integrated Understanding of Intellectual Functioning and Development. (In) Motivation, Emotion, And Cognition Integrative Perspectives on Intellectual Functioning and Development (Edt. D.Y. Dai \& R. J. Sternberg). Taylor \& Francis: New Jersey.

Deci, E. L., \& Ryan, R. M. (2000). The "what" and "why" of goal pursuits: Human needs and the self-determination of behavior. Psychological Inquiry, 11(4), 227-268.

Dweck, C. S., Mangels, J. A. \& Good, C. (2008). Motivational Effects on Attention, Cognition, and Performance (In) Motivation, Emotion, And Cognition Integrative Perspectives on Intellectual Functioning and Development (Edt. D.Y. Dai \& R. J. Sternberg). Taylor \& Francis: New Jersey.

Downing, J.H. \& Rebollo, J. (1999). Parents' Perceptions of the Factors Essential for Integrated Physical Education Programs. Remedial and Special Education, 20, (3) 152-159.

Froy, F. \& L. Pyne (2011), "Ensuring Labour Market Success for Ethnic Minority and Immigrant Youth", OECD Local Economic and Employment Development (LEED) Working Papers, 2011/09, OECD Publishing. http://dx.doi.org/10.1787/5kg8g210547ben

Handley, R. (2010). Increasing learning motivation and skills through computer technology for students with behavioral and/or learning difficulties. Premier's Teacher Scholarship Reports Volume 7 Department of Premier and Cabinet NSW. 
Heafner, T. (2004). Using technology to motivate students to learn social studies. Contemporary Issues in Technology and Teacher Education, 4(1), 42-53.

Hocutt, A. M. (1996). Effectiveness of Special Education: Is Placement the Critical Factor? The Future of Children Special Education for Students with Disabilities. I (6-1), 77-102.

Kara, A. (2008). İlköğretim Birinci Kademede Eğitimde Motivasyon Ölçeğinin Türkçeye Uyarlanmas1 [The Turkish Adaptation of Motivation Scale in Elementary Education First Stage] Ege Eğitim Dergisi. (9) 2, 59-78.

Klingner, J. K., Vaughn, S., Schumm, J. S., Cohen, P. \& Forgan, J. W. (1998). Inclusion or Pull-Out: Which Do Students Prefer? Journal of Learning Disabilities, 31 (2), 148-158.

Kutlu, M. \& Kaya, A. (2005). Bireyi tanıma ve bireyi tanıma teknikleri. İçinde psikolojik danışma ve rehberlik. [Student appraisals and student appraisal technigues in counseling and guidance] Ani: Ankara.

Kuzgun, Y. (1997). Rehberlik ve psikolojik danisma. [Guidance and counseling]. Ankara: ÖSYM Yayınları.

Levy, S., \& Campbell, H. (2008). Student Motivation: Premise, Effective Practice and Policy. Australian Journal of Teacher Education, 33(5). http://dx.doi.org/10.14221/ajte.2008v33n5.2

Nazli, S. (2011). Kapsamli gelisimsel rehberlik program. [Comprehensive developmental guidance program]. Ankara: Ani.

ORGM, O. (2015). Kaynastirme yoluyla egitim uygulamalari. Retrieved October 15, 2015, from http://orgm.meb.gov.tr/www/kaynastirma-yoluyla-egitim-uygulamalari-kilavuzkitapcigi-yayimlandi/icerik/56111.

Ozguven, I.E. (1997). Bireyi tanima teknikleri. [Appreisal of students]. Ankara: PDRM Yayınlari.

Parsons, J. J. \& Oja, D. (2014). New Perspectives on computer Concepts 2014, Comprehensive. Boston: Cengage Learning.

Pascual-Leone, J. \& Johnson, J. (2008). Affect, Self-Motivation, and Cognitive Development: A Dialectical Constructivist View. (In) Motivation, Emotion, And Cognition Integrative Perspectives on Intellectual Functioning and Development (Edt. D.Y. Dai \& R. J. Sternberg). Taylor \& Francis: New Jersey.

PDR-DER, (2007). Psikolojik danışma ve rehberlik alanında çalışanlar için etik kurallar [Ethic Conducts for workers who are in counseling and guidance discipline]. PDR-DER: Ankara.

Psikin, M. (2006). Ozsaygiyi Gelistirme Egitimi. İlkogretimde Rehberlik (Edt. Yildiz Kuzgun). Nobel: Ankara.

Ryan, R. M., \& Deci, E. L. (2000). Self-determination theory and the facilitation of intrinsic motivation, social development, and well-being. American Psychologist, 55(1), 68-78.

Smid, M. (2011). Talent development in youth work A study on the successful factors of talent development programmes aimed at the empowerment of adolescents in disadvantaged urban areas. Unpublished Master Thesis Utrecht University \& Netherlands Youth Institute.

Smith, L., Sinclair K., \& Chapman, E. (2002). Students' goals, self -efficacy, self-handicapping, and negative affective responses: an Australian senior school student study. Contemporary Educational Psychology, 27, pp. 471-485.

Sinop RAM (2012). "Sorunlar ve Üniversite İşbirlikleri” Rehberlik ve Araştırma Merkezi Toplantıs1 Tutanaklar1. [Problems and University Partnership Guidence and Research Center Meeting] Sinop: RAM.

Star, R. S., Chen, J. A. Taylor, M. W., Durkin, K., Dede, C. \& Chao, T. (2014) Studying technology-based strategies for enhancing motivation in mathematics. International Journal of STEM Education 1 (7) 1-19 doi:10.1186/2196-7822-1-7

Thorsen, C. (2009). Tech Tactics: Technology for Teachers ( $3^{\text {rd }}$ Edt.) Boston: Pearson.

Trock, M. (2009). Key skills for the labor market and input for portfolio. Innovation, Creativity and Accountability Learning Forum London, 22-24 June 2009. 
Usakli, H. (2006). Drama temelli grup rehbeberliginin ilkogretim V. sinif ogrencileirnin arkadaslik iliskileri, atilganlık duzeyi ve benlik-saygisina etkisi [The Effect of Group Guidance Based on Drama on Elementary School $5^{\text {th }}$ Grades Students' Friendship Relations, Assertiveness Level and Self-Esteem]. Unpublished PhD Thesis Dokuz Eylul University: Izmir

Vallerand, R.J., Pelletier L. G., Blais, M.R., Briere, N.M., Senecal, C., \& Vallieres, E. F. (1992). The academic motivation scale: a measure of intrinsic, extrinsic, and amotivation in education. Educational, and Psychological Measurement, 52, 1003-1017.

Van de Maele, M. (2009). The C-Stick project: innovative practices for assessing key competencies. Innovation, Creativity and Accountability. Learning Forum London, 2224 June 2009.

Yesilyaprak, B. (2002). Egitimde rehberlik hizmetleri. [Guidance services in education]. Ankara: Nobel Yayın.

Youth Competence Centers (2013) JES Antwerp-Case2-C-stick-Paper e-portfolio policy and implementation (Retrieved November 032013 from URBACT). 